\title{
PERANCANGAN SISTEM INFORMASI MARKETING BERBASIS WEBSITE PADA PERUSAHAAN DISTRIBUTOR PT. SBM
}

\author{
Sugiarto Hartono \\ Program Studi Sistem Informasi Universitas Bina Nusantara Jakarta, Indonesia \\ E-mail: shartono@binus.edu
}

Submission date : 2020-05-02

Accepted date: 2020-05-12

\begin{abstract}
Today, the use of the internet among the public is increasing. This gives a fairly large number in the business world specifically commercial companies. The internet makes it easier for companies to carry out sales activities, for example in marketing, sales, customer relations, or supplier relations. The objectives of the study were approved and a web application was made that made it easy for PT. SBM and other companies to promote its products to the general public. General problems at PT. SBM is limited in funds and resources for approval of a product. Therefore, we need a website that can help introduce or promote products that will be sold to the general public regardless of distance and time, as well as saving promotional costs. Data collection methods used are through surveys, interviews, and literature studies. The application design method uses the Object Oriented Analysis Diagram (OOAD) method which is divided into 2 processes, namely analysis and design. The research results consist of a web that can promote company products or individuals that are more effective and efficient. The conclusion of this research is the production of web-based e-marketing that can support companies or individuals in supporting their products.
\end{abstract}

Keywords: Internet, Promotion, Products, Web.

\begin{abstract}
ABSTRAK
Dewasa ini, penggunaan internet di kalangan masyarakat semakin meningkat. Hal ini memberikan dampak yang cukup besar dalam dunia bisnis khususnya perusahaan komersial. Internet menjadikan perusahaan lebih mudah melakukan kegiatan penjualan, misalnya dalam bidang pemasaran, penjualan, hubungan dengan pelanggan, ataupun hubungan dengan pemasok. Tujuan penelitian ialah merancang dan menghasilkan sebuah aplikasi berbasis web yang mempermudah PT. SBM dan perusahaan lain maupun perorangan untuk mempromosikan produk-produknya kepada khalayak ramai. Permasalahan umum pada PT. SBM adalah terbatasnya dana serta sumber daya untuk mempromosikan suatu produk. Karena itu, diperlukan sebuah website yang dapat membantu memperkenalkan atau mempromosikan produk-produk yang akan dijual kepada khalayak ramai tanpa memandang jarak dan waktu, serta menghemat biaya promosi. Metode pengumpulan data yang digunakan yaitu melalui survei, wawancara, dan studi kepustakaan. Metode perancangan aplikasi menggunakan metode Object Oriented Analysis Diagram (OOAD) yang dibagi menjadi 2 proses yaitu analisis dan perancangan. Hasil penelitian berupa web yang dapat mempromosikan produk-produk perusahaan maupun perorangan secara lebih efektif dan efisien. Kesimpulan dari penelitian ini ialah dihasilkannya e-marketing berbasis web yang dapat mendukung perusahaan maupun perorangan dalam mempromosikan produk-produknya.
\end{abstract}

Kata Kunci: Internet, Promosi, Produk, Web.

\section{PENDAHULUAN}

Dewasa ini, penggunaan internet di kalangan masyarakat semakin meningkat. Hal ini memberikan dampak yang cukup besar dalam dunia bisnis khususnya perusahaan komersial. Internet menjadikan perusahaan lebih mudah melakukan kegiatan penjualan, misalnya dalam bidang pemasaran, penjualan,hubungan dengan pelanggan, ataupun hubungan dengan pemasok.
Internet merupakan dasar dari kegiatan emarketing. E-marketing adalah kegiatan perusahaan dalam memasarkan produk dan jasa yang dilakukan dengan media elektronik atau internet (Dafe Chaffey, 2009).

E-marketing adalah penggunaan teknologi informasi dalam proses membuat, berkomunikasi, dan memberikan nilai (value) kepada pelanggan. E-marketing mempengaruhi pemasaran tradisional dalam dua cara. 
Pertama, e-marketing meningkatkan efisiensi dalam fungsi pemasaran tradisional. Kedua, teknologi dari e-marketing merubah banyak strategi pemasaran. Hasil perubahandalam model bisnis baru ini dapat menambah nilai (value) pelanggan dan meningkatkan keuntungan perusahaan (Strauss, J., \& Frost, 2012).

Perkembangan perusahaan di Indonesia yang semakin meningkat menimbulkan persaingan yang ketat antar perusahaan. PT. SBM bergerak dalam bidang penjualan bahan makanan dalam kemasan. Yang merupakan satu dari banyak perusahaan komersial yang membutuhkan alat untuk memasarkan produk dan memilih emarketing untuk meningkatkan penjualan. Permasalahan pada PT. SBM ialah pemasaran dengan brosur, spanduk, dan sebagainya merupakan cara lama dan tidak efektif karena tidak dapat menjangkau pasar secara luas.

Persaingan yang semakin ketat membuat perusahaan harus mencari cara untuk mendapatkan nilai lebih dibandingkan pesaingnya. Selain itu, waktu juga menjadi masalah dalam pemasaran karena perusahaan tidak dapat memasarkan produk selama 24 jam.

PT. SBM membutuhkan e-marketing sebagai cara baru dalam pemasaran produk untuk memaksimalkan penjualan. Dengan e-marketing, perusahaan dapat menjangkau pasar lebih luas, tidak hanya masyarakat sekitar, tetapi juga masyarakat luas bahkan sampai mancanegara. Emarketing memberikan suatu nilai lebih untuk perusahaan yang dapat menjadi keunggulan perusahaan dibandingkan dengan pesaing sehingga dapat menarik lebih banyak pelanggan. Perusahaan dapat memasarkan produk dengan waktu yang tidak terbatas dan pelanggan juga dapat mengakses produk perusahaan tanpa dibatasi tempat dan waktu.

\section{METODE PENELITIAN}

Metode penelitian yang digunakan dalam penelitian ini antara lain:

Melakukan survei langsung ke PT. SBM untuk mendapatkan informasi tentang produkproduk bahan makanan dalam perusahaan (Sani, 2018).

1. Melakukan wawancara dengan pengguna

2. Melalui studi kepustakaan untuk mencari data dan informasi serta landasan teori dari berbagai sumber, seperti buku dan internet.

Metodologi perancangan yang digunakan dalam e-marketing adalah Metode Object
Oriented Analysis Diagram berupa (Indrajani, 2011):

1. Metode Analisis

Metode Analisis yang digunakan adalah OOA

(Object Oriented Analysis). OOA (Object

Oriented Analysis) adalah semua objek yang melakukan suatu pekerjaan dalam sistem dan menunjukan ikatan antara pengguna, dan mencari apa yang dibutuhkan untuk menyelesaikan pekerjaan tersebut. Object adalah suatu hal dalam sistem komputer yang dapat merespon pesan. Dengan metode Object Oriented Analysis (OOA) dapat digambarkan dengan berbagai macam diagram pendukung seperti Class Diagram, Activity Diagram, Use Case, Use Case Description, Event Table, ERD.

2. Metode Perancangan

Metode perancangan yang digunakan adalah OOD (Object Oriented Design). OOD (Object Oriented Design) adalah jenis objek yang diperlukan untuk berkomunikasi dengan orang dan perangkat dalam sistem, menampilkan bagaimana cara penyelesaian suatu masalah. Dengan metode Object Oriented Design (OOD) dapat digambarkan dengan berbagai macam diagram pendukung seperti System Sequence Diagram, First Cut Sequence Diagram. Berdasarkan penjabaran kebutuhan yang telah dilakukan sebelumnya, disiplin ini kemudian bertujuan untuk merancang solusi dari sistem yang akan dibuat dengan enam aktivitas utam diantaranya:

a. Mendesain support services architecture dan deployment environment

$b$. Mendesain software architecture

c. Mendesain usecase realizations

d. Mendesain database

e. Mendesain sistem dan user interface

f. Mendesain sistem security dan control

\section{HASIL DAN PEMBAHASAN}

\section{Performance}

Masalah Performance Marketing pada PT SBM, bahwa system tidak mengikuti perkembangan IPTEK terutama dibidang marketing, ini disebabkan terbatasnya ketersediaan SDM yang ahli di bidangnya.

Solusi Masalah Performance :

1. Peningkatan SDM atau Rekrut SDM di bidang IPTEK guna menunjang kemampuan system sehingga strategi pemasaran dapat berjalan maximal dan mencapai sasaran yang diinginkan.

2. SDM dituntut untuk selalu melakukan inovasi terhadap system dengan mengikuti 
perkembangan pasar sehingga dapat bersaing dengan para kompetitor dalam penerapan strategi pemasaran dalam dunia marketing.

\section{Information}

Masalah Informasi Marketing pada PT SBM belum berjalan dengan baik, karena belum mamanfaatkan sarana teknologi internet secara maksimal. sehingga segala informasi yang berkaitan dengan dunia marketing tidak sampai atau berjalan dengan lambat.

Solusi Masalah Informasi ialah Marketing Memaksimalkan sarana internet dengan meningkatkan pengetahuan SDM atau jika diperlukan rekrut SDM yang sesuai criteria \& ahli di bidang informasi sehingga system informasi marketing dapat berjalan maksimal, akurat, tepat waktu dan relevan.

\section{Economic}

Masalah Economic Marketing ialah Biaya Kegiatan Marketing PT SBM terutama dibidang promotion masih belum seimbang atau secara percentage masih lebih besar dari hasil akhir yang tercapai atau yang diingin management marketing, penyebabnya amtara lain: pembuatan material penunjang Promotion mayoritas atau dominan masih menggunakan material fisik yang memerlukan biaya yang cukup tinggi (percetakan, brosur, spanduk.. etc). Penggunaan kertas kerja secara fisik yang berlebihan karena system link komputerisasi masih belum berjalan maksimal dalam kegiatan pemasaran.

Solusi Masalah Economic Marketing ialah Minimalis pembuatan, penggunaan Material Promotion dan kertas kerja sebagai sarana pemunjang marketing dengan memanfaatkan sarana teknologi digital, internet dan link sistem informasi sehingga dapat menekan biaya marketing dan pada akhirnya tercapai keseimbangan cost dan benefit dalam kegiatan marketing.

\section{Control}

\section{PT.SBM}

Masalah Control Pada System Pemasaran

1. Keamanan data masih lemah, mudah diakses sembarang user.

2. Adanya Potensi Error Data.

3. Akurasi data meragukan berakibat informasi yang dibutuhkan management Pemasaran tidak maksimal.

4. Update Data belum tepat waktu sehingga menghambat pengembangan Pemasaran.

Solusi Masalah Control ialah Segera lakukan perbaikan system komputerisasi, analisa dan evaluasi struktur database, edit dan update sesuai kebutuhan system yang dikehendaki.

\section{Efficiency}

Masalah Efficiency Marketing PT. SBM ialah Kegiatan Marketing masih dominan dengan cara konvensional sehingga waktu, tenaga dan biaya terbuang sehingga dari segi efisien Marketing tidak berjalan maksimal seperti apa yang dikehendaki.

Solusi Efficiency Marketing ialah Minimalis kegiatan Marketing dengan cara konvensioanal dengan memanfaatkan sarana Teknologi dan selalu mengikuti perkembangannya (Connolly, Thomas and Begg, 2010).

\section{Service}

Masalah Service Bidang Marketing PT. SBM ialah Sistem tidak fleksibel membuat informasi terhambat, kurang effektif, sehingga sulit menerapkan customer relationship karena dukungan sistem data belum maksimal .

Solusi masalah service bidang marketing ialah evaluasi dan analisa sistem yang sudah berjalan dan lakukan perbaikan system sehingga dapat menunjang kegiatan service ataupu informasi terhadap semua Relasi dan management Marketing dapat berjalan afektif sebagaimana yang dikehendaki.

Berikut adalah usecase diagram dari sistem marketing berbasis website yang diusulkan:

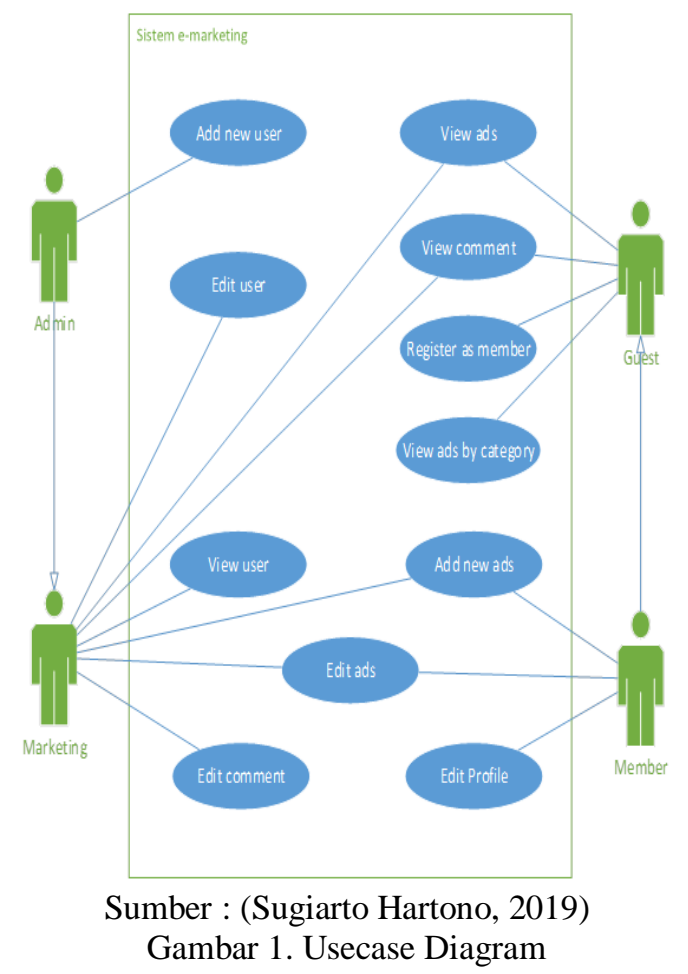

Rancangan database yang diusulkan untuk sistem e-marketing tersebut digambarkan sesuai ERD di bawah ini: 


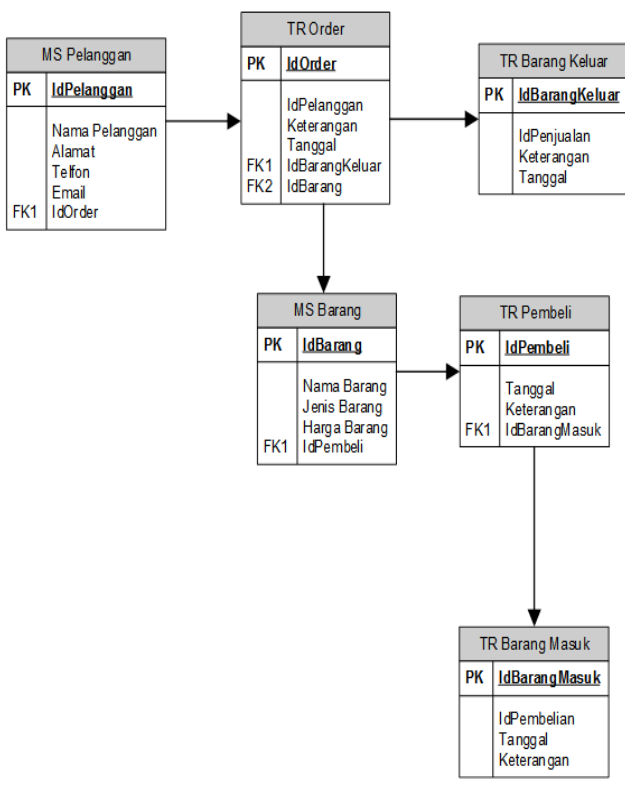

Sumber : (Sugiarto Hartono, 2019) Gambar 2. Entity Relationship Diagram

Berikut adalah proses bisnis usulan dari emarketing tersebut:

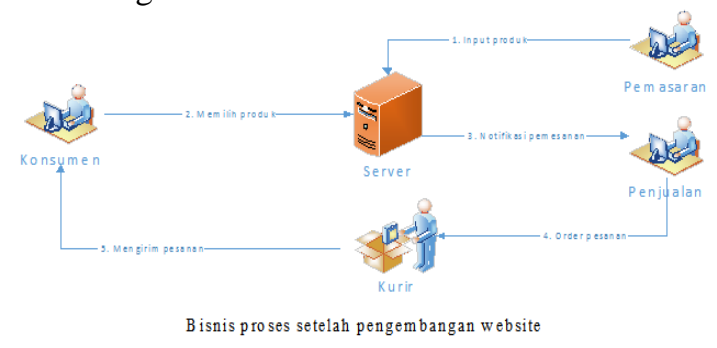

Sumber : (Sugiarto Hartono, 2019)

Gambar 3. Proses Bisnis Yang Diusulkan

Berikut adalah beberapa tampilan user interface untuk sistem $e$-marketing yang diusulkan:

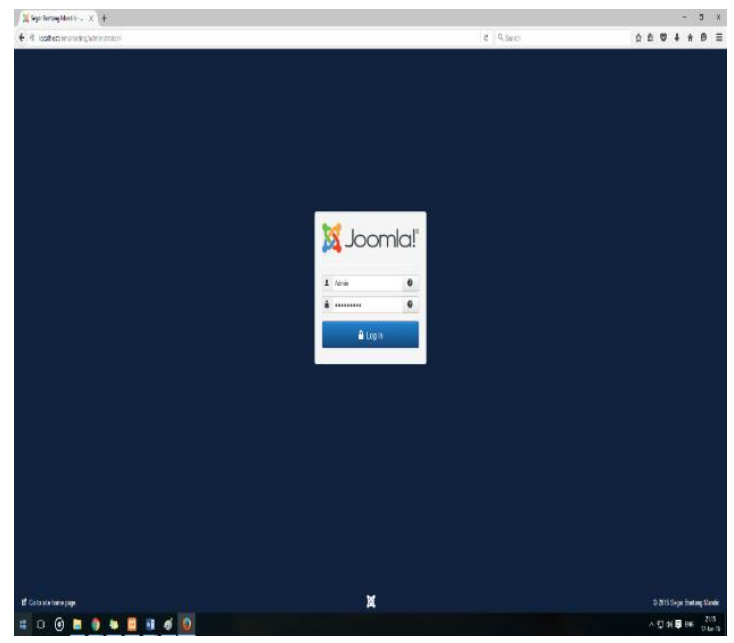

Sumber : (Sugiarto Hartono, 2019) Gambar 4. Halaman Login Admin
Gambar 4. merupakan layar login yang digunakan oleh admin dan marketing untuk masuk ke halaman back office.

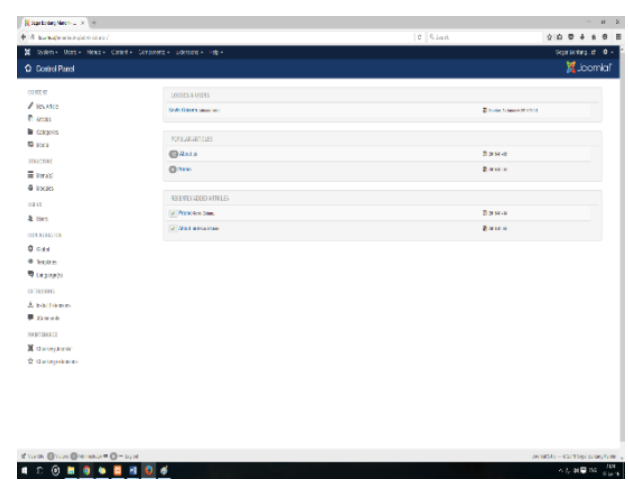

Sumber : (Sugiarto Hartono, 2019) Gambar 5. Halaman Beranda Back Office (Admin)

Gambar 5. merupakan tampilan halaman beranda back office. Semua marketing dan admin dapat login ke halaman ini. Tampilan user interface admin dan marketing memiliki sedikit perbedaan, karena hak akses marketing lebih terbatas dibandingkan dengan admin.

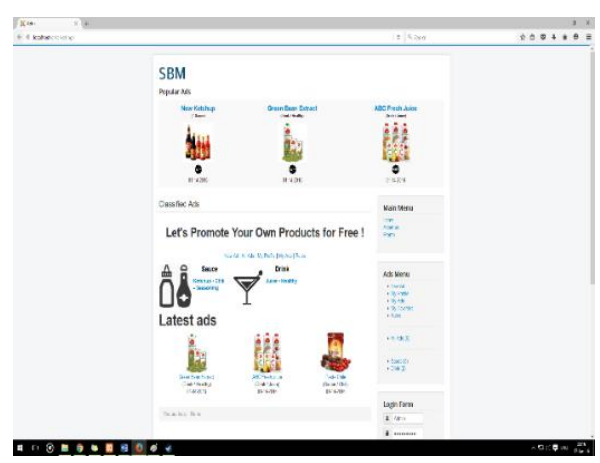

Sumber : (Sugiarto Hartono, 2019)

Gambar 6. Halaman Beranda

Gambar 6. menunjukkan halaman Beranda dari website e-marketing PT. SBM.

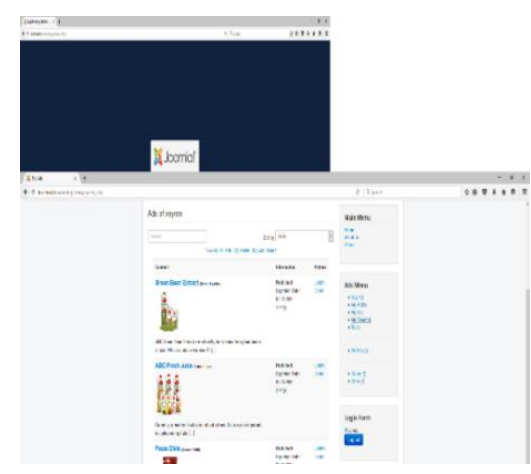

Sumber : (Sugiarto Hartono, 2019)

Gambar 7. Halaman My Ads

Gambar 7. menunjukkan halaman daftar iklan yang telah dibuat oleh user 
KESIMPULAN

Berdasarkan pembahasan sebelumnya didapatkan kesimpulan sebagai berikut :

Website e-marketing pada PT. SBM mempermudah pengguna untuk mempromosikan produknya ke seluruh cangkupan daerah tanpa memandang jarak dan waktu. Dan pengguna website e-marketing dapat dengan mudah memperoleh informasi maupun promo terbaru dari produk yang diinginkan. Level pengecekan keakuratan dan kebersihan data Akuntan dan Penilai masih pada level Staf. Untuk itu pada MDM dibuat tahapan approval data dimana hasil kerja staf ada penanggung jawabnya agar data yang dihasilkan benar benar terjamin.

\section{DAFTAR PUSTAKA}

Connolly, Thomas and Begg, C. (2010). Database Systems A Practical Approach to Design, Implementation, and Management Fifth Edition. Pearson Education.

Dafe Chaffey. (2009). E-Business and e-commerce management: strategy Implimentation, and practice (Printece $\mathrm{H}$ ).

Indrajani. (2011). Perancangan Basis Data All in 1. Alex Media Komputindo.

Sani, A. (2018). Analisa Penjualan Retail Dengan Metode Association Rule Untuk Association Rule Untuk Pengambilan Keputusan Strategis Perusahaan : 2(June 2016), 34-50.

Strauss, J., \& Frost, R. (2012). E-marketing. Pearson Prentice Hall.

Sugiarto Hartono. (2019). Perancangan Sistem Informasi Marketing Berbasis Website Pada Perusahaan Distributor PT. SBM. 
